\title{
POPOVICIU TYPE INEQUALITIES VIA HERMITE'S POLYNOMIAL
}

\author{
SAAD IHSAn Butt, Khuram Ali KHAN AND Josip PEČArić
}

Abstract. We obtain useful identities via Hermite interpolation polynomial, by which the inequality of Popoviciu for convex functions is generalized for higher order convex functions. We investigate the bounds for the identities extracted by the generalization of the Popoviciu inequality using inequalities for the Čebyšev functional. Some results relating to the Grüss and Ostrowski type inequalities are constructed.

Mathematics subject classification (2010): Primary 26D07, 26D15, 26D20, 26 D99.

Keywords and phrases: Convex function, divided difference, Hermite interpolation, Čebyšev functional, Grüss inequality, Ostrowski inequality, exponential convexity.

\section{REFERENCES}

[1] R. P. Agarwal, P. J. Y. Wong, Error Inequalities in Polynomial Interpolation and Their Applications, Kluwer Academic Publishers, Dordrecht/Boston/London, 1993.

[2] P. R. BEES ACK, On the Green's function of an N-point boundary value problem, Pacific J. Math. 12 (1962), 801-812.

[3] S. I. Butt, K. A. Khan And J. PeČarić, Popoviciu Type Inequalities via Green Function and Generalized Montgomery Identity, Math. Inequal. Appl. 18 (4) (2015), 1519-1538.

[4] P. Cerone, S. S. Dragomir, Some new Ostrowski-type bounds for the Čebyšev functional and applications, J. Math. Inequal. 8 (1) (2014), 159-170.

[5] L. Horváth, K. A. KHAN AND J. PeČARIĆ, Combinatorial Improvements of Jensens Inequality / Classical and New Refinements of Jensens Inequality with Applications, Monographs in inequalities 8, Element, Zagreb, 2014, pp. 229.

[6] A. Yu. LEVIn, Some problems bearing on the oscillation of solutions of linear differential equations, Soviet Math. Dokl., 4 (1963), 121-124.

[7] K. A. KHAN, J. PEČARIĆ AND I. PERIĆ, Differences of weighted mixed symmetric means and related results, Journal of Inequalities and Applications, 2010, Article ID 289730, 16 pages, (2010).

[8] K. A. KhAN, J. PEČARIĆ AND I. PERIĆ, Generalization of Popoviciu Type Inequalities for Symmetric Means Generated by Convex Functions, J. Math. Comput. Sci., 4 (6) (2014), 1091-1113.

[9] C. P. Niculescu, The Integral Version of Popoviciu's Inequality, J. Math. Inequal. 3 (3) (2009), 323-328.

[10] J. PeČarić, F. Proschan and Y. L. Tong, Convex functions, Partial Orderings and Statistical Applications, Academic Press, New York, 1992.

[11] T. Popoviciu, Sur certaines inégalités qui caractérisent les fonctions convexes, Analele Ştiinţifice Univ. “Al. I. Cuza”, Iasi, Secţia Mat. 11 (1965), 155-164.

[12] P. M. Vasić And LJ. R. Stanković, Some inequalities for convex functions, Math. Balkanica. 6 (44) (1976), 281-288. 